Archivum, LXV, 2015, pp. 91-132

\title{
Vetusta: una apática revuelta o Ana Ozores en el espejo de Petra
}

Recibido: 24/04/2015

Aceptado: 31/08/2015

\section{RESUMEN:}

Se propone una nueva lectura de la obra maestra de Leopoldo Alas La Regenta en tres apartados. En el primero se precisan los aspectos que permiten incluir la novela dentro de los principios esenciales del Bildungsroman; en el segundo, el eje consiste en la determinación de los motivos por los cuales los protagonistas se resignan a una "revuelta" tardía y superficial, fruto de una apatía congénita; el tercero - tal vez el más original - asume la pareja Ana / Petra como revisión de una estructura paralelística que preside la obra, tal vez en un sentido casi musical.

PALABRAS CLAVE: novela, aduterio, Leopoldo Alas.

\section{ABSTRACT:}

This article proposes a new interpretation of Leopoldo Alas' masterpiece, La Regenta in three sections. The first section specifies the features that allow the novel within the fundamental principles of the Bildungsroman; the second section turns around the axis determining the reasons why the main characters surrender to a late and superficial "revolt" as a consequence of a congenital apathy; and the third one - which is probably the most original one-proposes the couple Ana / Petra as a revision of a paralelistic structure that dominates the whole play, in an almost musical sense.

KEY-WORDS: novel, adultery, Leopoldo Alas. 


\section{De vuelta a Vetusta}

El tema del adulterio atraviesa con profundidad la literatura europea del siglo XIX, tanto que constituye, a partir del arquetipo Madame Bovary, un subgénero de la novela, con un protagonista invariablemente femenino: podemos hablar al respecto de otra derivación literaria del double standard, una prueba más del enorme alcance simbólico de la definición de la identidad, de la femineidad ${ }^{1}$. Sin embargo, la incerteza de género, entre autor y protagonista, siempre aparece declarada, ya desde el modelo que proporciona el arquetipo, hasta la subsección de la novela realista que aparece configurada con el lema de novela de adulterio. Si pudo ser Flaubert quien proclamara Emma Bovary c'est moi...2 ${ }^{2}$, para luego inducir a Leopoldo Alas a definiciones tal vez menos radicales, aunque paralelas. En esto, creo que una sintonía merecida distinga el caso de Alas respecto al de otros grandes escritores, desde Fontane hasta Tolstoi, pasando por Capuana y Eça de Queirós. Clarín, de hecho, como Flaubert, describe las perturbaciones de su heroína de papel con la típica alternancia entre la tierna participación y el sarcasmo ardiente que siempre se encuentra en la escritura autobiográfica. También en La Regenta ${ }^{3}$ los toscos intentos de transferir a dimensión auto reflexiva y literaria el auto análisis de la protagonista reflejan la exigencia que ya había tenido Emma de elevarse au-dessus de milieu. A diferencia de lo que manifiestan otras mujeres, protagonistas narradoras de historias sentimentales que desembocan en representación de la sexualidad sentimental, sin ideologización, aferrada por justificaciones románticas, Emma y Ana buscan en cambio una apología laica a su comportamiento, una justificación "artística".

1 Nicola Palladino, Ultima Musa. Percorsi della modernità tra neoclassicità e barocco, Bonanno, Acireale-Rima 2010.

2 La tradición es bien sabido que sea apócrifa, sin embargo ha llegado a ser canónica a partir de la anotación de René Descharmes, Flaubert. Sa vie, son caractère et ses idées avant 1857, Ferroud, Paris 1909.

3 Elijo como edición de referencia la de Joan Oleza, en Letras Hispánicas (Cátedra, Madrid 1984, 2 vv.). 
Una justificación que las une indisolublemente a las ambiciones y angustias de sus autores y creadores. En esto, las obsesiones místicas - tan marcadas en el personaje de la Ozores - carecen de religiosidad personal y responden a un ansia de distinción y elevación moral.

A partir de este contexto general, con la particularidad propia post romántica de la cultura del siglo XIX, la infracción del vínculo matrimonial por parte de la mujer (esposa fiel, adultera o amante perversa: las diferencias son secundarias) se convierte en materia literaria a través de la cual se hace posible interrogar al sistema de las estructuras sociales y de la cultura de una época, los procesos emocionales y sicológicos de los personajes, y, podemos suponer que la tentación del autobiografismo, pudo catalogar el individualismo enfrentado a las afirmaciones colectivas. Porque fue esta la cuestión de fondo que se inscribe - y describe - la irresolución de toda una cultura, de todo un mundo. Encontramos en esta actitud la «macro-metáfora de la condición de precariedad típica del equilibrio de la micro-sociedad burgue$\mathrm{sa}^{4} \gg$. El enlace con la condición económico-social de la burguesía es vital porque es sólo en el interior de este microcosmos y de sus equilibrios específicos donde se aprueba la hegemonía, que la fidelidad femenina, o al contrario, la absoluta monogamia garantizada por el aislamiento religioso ${ }^{5}$, puede asumir un alcance

4 Giuseppe Grilli, “Leopoldo Alas Clarín y su obra maestra: La Regenta”, Boletín de la Real Academia de Buenas Letras de Barcelona, XLVII, 1999-2000, p. 476. Ver Id., Cronache del disamore. Percorsi del romanzo iberico tra XIX e XX secolo, Dialogoi. Studi comparatistici, Aracne editrice, Roma, 2008 (segunda edición corregida y puesta al día, ivi, 2014).

5 Tema reanudado y desarrollado en la novela en el episodio del convento de clausura que ejerce una función represiva, prácticamente militar, en la conexión referencial a la permanente agitación carlista y legitimista instrumentalizada por el Magistral a garantía de su poder, o sea del privilegio "burgués" que paga, con la cobertura ideológica a la causa ultramontana y reaccionaria, su aceptación entre los aristócratas de la clase. Pero ninguna sombra ideológica se eclipsa en esta tragedia, solo la lujuria de Fermín de Pas a la base de esa, como afirma sin titubear la madre Paula («las de Carraspique se han metido monjas por culpa tuya, y una de ellas está 
totalizador. De la inversión simbólica en el tema del adulterio depende la capacidad elocuente de una específica construcción de las relaciones de género. La crisis, y la mutación de estas últimas, hacia finales del siglo XIX, encuentra espacio en las novelas que constituyen el micro género del cuento de adulterio ${ }^{6}$, así se proporciona un territorio de lo literario que se presta al análisis de esas mutaciones y alcances simbólicos. Prueba de esto es la evolución de la presencia de las mujeres en las sociedades occidentales a medida que nos acercamos a finales de siglo, cuando surge la cuestión familiar en el cuadro de las más amplias mutaciones del sistema político gracias a lo que Ortega y Gasset llamará la rebelión de las masas.

La Regenta de Leopoldo Alas, Clarín, surge dentro de este contexto y es, quizás consecuentemente, una novela que se distingue por su extraordinaria exactitud que funciona en todos los niveles del texto, desde el tema hasta la forma, desde la construcción de los personajes hasta el lenguaje. Es una novela que dialoga con la tradición literaria española $\mathrm{y}$, a la misma vez, con los progresos coevos de las literaturas europeas, sobre todo en lo que concierne a la novela naturalista y al subgénero de la novela en cuyo interior se inscribe el texto, que es sólo un aspecto de la exactitud de la obra maestra. La relación de obvia derivación con el Flaubert

muriendo tísica por culpa tuya también, como si tú fueras la humedad y la inmundicia de aquella pocilga»), Ed. Oleza, I, 11, p. 484.

6 Biruté Ciplijauskaité, La mujer insatisfecha. El adulterio en la novela realista, Edhasa, Barcelona, 1984 examina además de Madame Bovary, Anna Karenina, Effi Briest, La Regenta y otros libros; habría que añadir a la lista algunos ejemplos italianos y, sobre todo Un drama familiar de Aleksandr Herzen, en el volumen, que es su obra maestra, expresión máxima del populismo ruso Biloe i Dumy 1867, (Passato e pensieri, primera tr. italiana, 1949). La cuestión familiar se discutió por mucho tiempo en España hasta el afirmarse de la dictadura franquista que pone en sordina la obra maestra clariniana hasta celebración de su publicación a mitad de los años ochenta del siglo XX; remito solo a a Geraldine M. Scanlon, La polémica feminista en la España contemporánea (1868-1974), Siglo XXI de España, Madrid 1976, pero recuerdo también a $M^{\underline{a}}$ del Pilar Oñate, El feminismo en la literatura española, Espasa-Calpe, Madrid 1938. 
de Madame Bovary, con la transposición que esto conlleva en las dinámicas de dicho texto, generando diferencias, en otro ámbito social, político y cultural, es una de las estrategias a través de las cuales Leopoldo Alas Clarín interroga explícitamente las posibilidades expresivas de la novela española de finales de siglo XIX, poniéndolas en relación con lo que estaba pasando en el resto de Europa y además, a través de las continuas referencias intertextuales que impregnan toda la novela, con la gran literatura ibérica de los siglos anteriores, en modo particular con la herencia del Quijote ${ }^{7}$.

De este tema tan vasto y, por la complejidad de la obra, quisiera tomar en consideración el aspecto, limitado pero importante, de la presencia en La Regenta de referencias metanarradoras a la novela en general con una extensión que va desde las escrituras de entretenimiento a las mitológicas, con referencias tanto a las historias profanas como a las religiosas. Toda esta amalgama, sin control, debido en máxima parte al carácter autodidacta de las lecturas de la protagonista, que brotan como vegetación semi silvestre de la caótica y diletante biblioteca del padre de la Ozores, nos entrega con precisión el rol ejercido por la figura paterna y uniparental en la formación intelectual y sentimental de la protagonista. Dicha influencia completa la percepción de sí misma que Ana Ozores desarrolla durante su infancia y adolescencia a través del tema religioso, desarrollándolo también en forma literaria, complicando su relación con la realidad, proclamada provinciana, de Vetusta. Esta acepción de "provincia", que tiene un significado esencialmente cultural, repercute en la vulgaridad de los tres protagonistas del libro: la heroína Ana, cuyas asimilaciones lectoras son un enredo sin concierto, su escritura es aproximativa en las cartas, como en la forma diarística, lo que, en conjunto, se traduce en el único dedo musical con el que trata

7 Sobre informes de la obra de Clarín con la herencia cervantina por una parte y el naturalismo por el otro véase Maria Rosaria Alfani, Il ritorno di Don Chisciotte. Clarín e il romanzo, Donzelli Editore, Roma 2000. La rica cosecha de remisiones intertextuales e interdiscursivos es en gran parte revelada detalladamente en la edición de Joan Oleza en Letras Hispánicas. 
de tocar en un piano. De la misma manera Mesía, que al final ella acoge como amante, es un don Juan de mala muerte entregado a conquistas fáciles, y no es una coincidencia si Frígilis, cuyo nombre revela el límite material contra el cual se estrella su ansia intelectual, lo define como un mequetrefe ${ }^{8}$. Por otro lado, aun como hombre político (es diputado en Cortes), la supremacía de don Álvaro Mesía es inexistente o ilusoria; en el plano político la ejerce por encomienda del Marqués de Vegallana, cubriendo un papel de representación que por su cuenta no sabría conquistar. En fin, también el Magistral, Fermín De Pas, no va más allá de la lección mal interpretada sacada de alguna revista de ultra frontera de la cual exhuma una visión positivista edulcorada, que podría dar sustancia a sus sermones desde el púlpito, pero éstos, en realidad, destacan una deformación cruel, es decir, ponen en evidencia su impietas dictada por la falta de vocación religiosa, además de la aproximación innata en su cultura de seminarista pueblerino. Del cuarto miembro del cuadrilátero, el marido mofado, Quintanar, no hay que hacer ninguna mención, puesto que él es simplemente una caricatura, un cómico, tanto en la acepción clásica de actor intérprete de la comedia áurea, como en el sentido moderno de una figura oblicua, incapaz de asumirse, ni siquiera por broma, como trágica?

Sin embargo, hacia finales de siglo son los mismos autores de novela los que ponen en discusión el rol del personaje, y se interrogan acerca de las repercusiones sociales de una educación sentimental y una formación de la identidad de género dejada en manos principalmente de la novela, sobre todo porque los modelos tradicionalmente propuestos resultan inadecuados a la

8 O peor: «Es un zascandil» en la definición de Frígilis en el último capítulo del libro (II, 300, p. 541 en la ed. Oleza, II). Es interesante notar que en el léxico de don Carlos como mequetrefe es apodado Chateaubriand (I, 4, p. 254).

9 Disiento en eso del estudio denso, y bien argumentado, de Enrico Di Pastena, “¿Don Víctor flaquea? Note a un personaggio de La Regenta?", Rivista di filologia e letterature ispaniche, 9 (2006), pp. 119-148. 
realidad contemporánea en rápida evolución. La construcción de personajes femeninos que contradicen las idealizaciones literarias de las relaciones entre los géneros, con el fin de conservar una mayor adherencia de la realidad social, es una de las maneras con que los autores, desde el realismo en adelante, enfrentan el problema del estatuto de la obra literaria en el interior de la sociedad moderna. El otro es la introducción en el texto de referencias metanarrativas en función de la novela, con implícitas reflexiones sobre el modo en que tal obra, con semejantes inserciones, genere un cambio respecto al pasado. Símiles estrategias aparecen en Tess of the d'Urbervilles de Thomas Hardy y en Nana, de Emile Zola, dos extremos de la narrativa coeva que se salen del vínculo del subgénero de adulterio de la cual es indudable la consistencia y, a veces, la proximidad. Por otro lado la novel anglosajona es uno de los pernios de la educación que Ana Ozores recibe de su aya anglo-española, que establece su programa educativo con todo lujo de detalles, demostrando así un notable dominio de esa literatura por parte del autor, que resulta crítico literario antes de efectuar una escritura creativa portadora de muchos rasgos de tendencia ensayista. En esto Clarín no solo demuestra conocer bien el tipo de cultura a la cual hace referen$\mathrm{cia}^{10}$, sino que con ingenio adelanta una deriva narrativa que será típica del siglo $X X$ en el que escribir cuentos es contextual a la crítica del cuento mismo. El pasaje dedicado a la educación de la protagonista, entre la infancia y la adolescencia, proporciona indicios sobre la formación recibida por Ana en su primera definición personal y la influencia de esta educación en su destino futuro. Sin entrar plenamente en el esquema y proyecto del Bildungsroman, los dos pilares de este acercamiento pedagógico son la Biblia y la novela, o mejor dicho, la novela inglesa de familia, el género estimable de la Inglaterra victoriana de la que proviene la misma institutriz Camila. Expresión de un sistema moral que sacudía la diferencia de género como principio organizador de

10 «Curaba el entendimiento y el corazón a los niños con píldoras de la Biblia y pastillas de novela inglesa para uso de las familias », ed. de J. Oleza, v. I, 4, p. 233. 
la vida personal y social, distribuyendo la experiencia entre las esferas opuestas de lo masculino y lo femenino, asignando a la mujer el rol de ángel del hogar. Este modelo de la literatura es el modelo de comportamiento que doña Camila trata de inculcar en Anita, un ideal de referencia sostenido por el recurso a una retórica que usa el lenguaje de la religiosidad cristiana: las "píldoras de la Biblia", seleccionadas para que no pongan en discusión los principios morales expresados por la literatura y no revelen las hipocresías y contradicciones ${ }^{11}$.

El texto de Alas denuncia la hipocresía de este (y de cualquier otro) sistema educativo y la fisura existente entre la idealización literaria y la realidad histórica, estableciendo al aya como a una "una grande hipócrita"12 (I, p. 233), cuyo comportamiento y sentimientos se contradicen con el ideal de pureza femenina al cual hacía propaganda la novel, como prejuicio de clase expresado en la separate spheres ideology. En lo que concierne al aspecto de la femineidad, sin embargo, destaca la paradoja de la fuerza de la lujuria como la pasión dominante en la institutriz, o sea, la única debilidad de la naturaleza humana que una mujer "respetable" no puede poseer, ya que le conviene manifestar su instinto sexual como ausente o marchito. Mientras que en lo que concierne al prejuicio de clase, Camila lo expresa a través del desprecio que dirige hacia la memoria de la madre de Ana, una humilde costurera italiana a quien el aristocrático don Carlos hiciera su esposa contra el parecer de su propia clase y el desagrado de las hermanas.

11 Cf. Maria Luisa Cerrón Puga, “Las confesiones de Ana. Modelos de introspección en La Regenta de Clarín". Cervantes. Revista del Instituto Cervantes en Italia, I (2001), pp. 143-169.

12 Es significativo que la acusación de hipocresía luego se vuelque sobre Ana Ozores por parte de las damas de Vetusta que ya han perdido la reputación, Visitación, Obdulia, como por parte de la doncella Petra, a la que poco le falta para colocarse como mujer pública, aunque con recato. 
Es importante tomar en serio, más allá de la ironía que caracteriza la descripción, los supuestos principios morales de la educación que Anita Ozores recibe por parte del aya anglo-española, porque el texto clariniano redime de este "gimnasio de moralidad inglesa" (I, p. 235) una serie de consecuencias para la evolución psicológica del personaje que repercuten a lo largo de la novela, y que acaban poniendo al personaje en una luz de poca sinceridad ${ }^{13}$.

La primera consecuencia y la más importante es la herida producida en Ana por el estigma negativo que le dejara su inocente fuga nocturna con el compañero de aventuras Germán por orden de su malvada institutriz. Ana no logra entender el sentido de la acusación con que Camila la increpa y tampoco comprende la culpa que la deshonra, simplemente porque siempre la mantuvieron lejos de todo lo que concernía a las relaciones sexuales y por lo tanto desconoce el sentido que la sociedad atribuye a ciertos comportamientos. La calumnia la expone a la mirada morbosa de los hombres desde que es niña y, sobre todo, la inhibe por temor de cometer otros errores, con la misma inconsciencia a sufrir más humillaciones: todo lleva a Ana a desconfiar de todo y todos y a autoexcluirse de los juegos de coquetería típicos de la adolescencia. A la mayor parte de las personas les aparecía orgullosa y altanera, cuando probablemente escondía una defensa de su propia entereza. La superficialidad de las relaciones con Quintanar, después de la boda, éstas acaban pareciéndole normales o por lo menos no suscitan en ella un claro sentido de repulsa, quizás justo en virtud de un rechazo genérico, inconsciente y antiguo, respecto a la sexualidad. Solo más adelante, el acercamiento con el inglés que le regala la célebre piel de tigre, suscitando envidia en Obdulia y Visitación, que intuyen un incipiente romance de adulterio entre los pliegues (o los pelos) del vello, o la inexorable toma de contacto con Vetusta y su materialidad irredimible, la convencen que podría tratarse de algo más.

13 Una atención monográfica al tema del personaje en el conjunto de la obra narrativa de Alas se debe a Maria Rosso Gallo, El narrador y el personaje. En el mundo de Leopoldo Alas “Clarín", Edizioni dell'Orso, Alessandria, 2001. 
No obstante la deriva hacia el otro, intuido sin llegar a conocerlo, había sido desdeñosamente rechazada por vulgar cuando la belleza perfecta de los años de fragante juventud la habían apartado del donador que había juzgado inconsistente, como inconsistente será Álvaro Mesía, acogido algunos años más tarde, con resignación en cuanto única expresión de una revuelta, posible sólo porque apática. Paso a comparar dos pasos decisivos para hacer plausible esta interpretación que demuestra la resignada evolución de la Ozores que acepta al amante más como maniquí que como figura viva:

En aquel momento vio a todos los vetustenses felices a su modo, entregados unos al vicio, otros a cualquier manía, pero todos satisfechos. Sólo ella estaba allí como en un destierro. «Pero jay! era una desterrada que no tenía patria a dónde volver, ni por la cual suspirar. Había vivido en Granada, en Zaragoza, en Granada otra vez, y en Valladolid; don Víctor siempre con ella; ¿qué había dejado ni a orillas del Ebro, el río del Trovador, ni a orillas del Genil y el Darro? Nada; a lo más, algún conato de aventura ridícula. Se acordó del inglés que tenía un carmen junto a la Alhambra, el que se enamoró de ella y le regaló la piel del tigre cazado en la India por sus criados. Había sabido más adelante que aquel
El frac, la corbata, la pechera, el chaleco, el pantalón, el clac de Mesía no se parecían a las prendas análogas de los demás. Ana vio esto sin querer, sin pensar apenas en ello, pero fue lo primero que vio. Se le figuraban ya todos los caballeros que andaban por allí, don Víctor inclusive, criados vestidos de etiqueta; todos eran camareros, el único señor Mesía. De todas maneras estaba bien don Álvaro; de frac era como mejor estaba. En todas partes parecía hermoso, dominaba a todos con su arrogante figura; allí, en el baile, debajo de aquella araña de cristal, que casi tocaba con la cabeza, era más elegante, más bizarro, más airoso que en cualquier otro sitio. El baile animado, ardiendo de voluptuosidad 
hombre, que en una carta — que ella rasgó- la juraba ahorcarse de un árbol histórico de los jardines del Generalife; "junto a las fuentes de eterna poesía y voluptuosa frescura', aquel pobre Mr. Brooke se había casado con una gitana del Albaicín. Buen provecho; pero de todas maneras era una aventura estúpida. La piel del tigre la conservaba, por el tigre, no por el inglés.» I,10, pp. fuerte y disimulada, era el cuadro propio para servir de fondo a la figura que ella, la pobre Ana, había visto tantas veces en sueños. II, 24, pp. 367-368.

El otro a quien alude, y al que aspira Fermín, y que ella rechaza con desdén, porque motivado por su "falta de preparación", o sea, emprender "amores con un canónigo", le parece cómico y poco digno, como inaugurar su vida amorosa, y la práctica de la sexualidad, con un sujeto a quien ella está prohibida. No es coincidencia que la familia y el cortejo sean las dos privaciones principales de las que Ana es víctima en la vida adulta, con el desesperado deseo de un hijo y su melancólica constatación de que nunca nadie le ha hablado de amor. Ana tiene una percepción deformada de la sexualidad en general, y en particular de la masculina, precisamente porque su primer momento de contacto con ese universo lo provee una mirada que le impone una sexualidad forzosa a pesar de su inmaduritas. Iriarte, el amante semiclandestino de Camila, es una figura fundamental porque compendia los motivos de la turbación provocada por las miradas dirigidas a ella (intencionalmente) indescifrables de parte de los hombres, tanto en espacios cerrados como abiertos: la Ozores es esquiva en los banquetes y salones como en la iglesia y en la calle.

Que esa mirada intuida, y, a menudo eludida, representara un viático hacia la lengua otra, o mejor, la lengua del otro, aparece 
bien reflejado en el capítulo IX donde se lleva a cabo el primer encuentro/choque con la chica que debería representar la disparidad/equivalencia, en edad adulta, de Camila: Petra ${ }^{14}$. De la misma manera que Camila no fue la tata cariñosa que habría debido tomar el puesto de la madre, que le fue sustraída doblemente, primero por la condición social y luego por la cancelación biológica con la muerte prematura, Petra nunca será la doncella fiel que subdivide su rol en un comportamiento que podría (debería) reencarnar a la sirvientalamiga de la comedia del siglo de oro. $\mathrm{O}$ bien lo es en una autorepresentación muy particular como cuando se asoma en la casa de De Pas y Teresina advierte inmediatamente la amenaza que la rubia azafranada puede constituir a los ojos siempre atentos y curiosos del señorito:

Teresina los espiaba desde la sombra en el pasadizo inmediato. El Magistral lo presumía y habló como si fuera delante de testigos.

- ¿Es usted criada de la señora de Quintanar?

-Sí, señor; su doncella.

- ¿Viene usted de su parte?

-Sí, señor; traigo una carta para Usía.

Aquel usía hizo sonreír al Provisor, que lo creyó muy oportuno.

- ¿Y no es más que eso?

- No, señor.

-Entonces..

- La señora me ha dicho que entregara

14 Cfr. G. Grilli, “La Regenta, I,9”, en A più voci. Omaggio a Dario Puccini, All'insegna del pesce d'oro, Milano 1994, pp. 179-186, ampliado en Id., Cronache del disamore, cit., pp. 117-136. 
a Usía mismo esta carta, que era urgente y los criados podrían perderla... o tardar en entregarla a Usía.

Teresina se movió en el pasillo. La oyó el Magistral y dijo:

-En mi casa no se extravían las cartas.

Si otra vez viene usted con un recado por escrito, puede usted entregarlo ahí fuera... con toda confianza.

Petra sonrió de un modo que ella creyó discreto y retorció una punta del delantal.

-Perdóneme Usía... - dijo con voz temblorosa y ruborizándose.

- No hay de qué, hija mía. Agradezco su celo.

(I, 10, pp. 477-478).

Se notan aquí que el carácter seductor de Petra, los celos de Teresina y, sobre todo, la íntima y (a lo mejor) involuntaria complicidad y el inextricable enlace que une a Petra a Ana en la esfera de las relaciones masculinas. Un vínculo que se percibe en la precaución con la cual ante la insinuación de ser "criada", Petra replica aclarando que ella es "doncella".

Sin embargo es Petra - como lo fue Camila - la única compañía concedida, la figura femenina que le permite salir de la casa y la ciudad para acercarse a la naturaleza sin pasar por intermediarios masculinos. El paseo que llevará a Petra hasta la fragua de su amante sin nombre, oculto bajo el disfraz del primo molinero, es para Ana el deseo insatisfecho de espontaneidad de expansión - palabra clave de la novela ibérica del siglo XIX -, que podrá realizarse de otra manera en las vacaciones en el Vivero. Ese momento le afectará inexorablemente por la decisión de los 
hombres y de la índole de las vacaciones de esa naturaleza (locus amoenus invertido). El Vivero, que ocupa capítulos decisivos y determinantes para la evolución del desenlace, ve el triunfo (apresurado y efímero), de la sexualidad de Petra, que obtiene la seducción del Magistral y una intimidad con la cual pondrá en acción su perfidia (la envidia femenina como envidia social). Pero, incluso en estos juegos e intercambios de roles, la clave es siempre la comparación con las formas y conceptos que representan los cimientos de la cultura áurea, donde el tema de la envidia, especialmente en la versión de la envidia erótica, es central ${ }^{15}$.

\section{Una apática revuelta}

Ana Ozores es el mayor símbolo de Vetusta hasta el punto de ser clasificada como una las maravillas de la región, identificada como Monumento igual a la Catedral. Desde el principio de la novela la identificación es directa; desde que la hermosa Ana recién casada con Quintanar asume una función que permite el comentario sin malentendidos inapropiados y se va de Vetusta para acompañar al marido en la toma de posesión de la Presidencia del Tribunal (Audiencia). Las expresiones del narrador no dejan lugar a dudas sobre la potencia viva de su figura emblemática:

En poco tiempo se consolidó la fama de aquella hermosura y Anita Ozores fue por aclamación la muchacha más bonita del pueblo. Cuando llegaba un forastero, se le enseñaba la torre de la catedral, el Paseo de Verano, y, si era posible, la sobrina de las de Ozores. Eran las tres maravillas de la población (I, 5, p. 276).

Un ¡adiós! llenó los ámbitos de la Plaza Nueva: era un adiós triste de verdad, era la despedida de la maravilla del pueblo; Vetusta en

15 Hago referencia aquí a mi Intrecci di vita. Intorno a «La Dorotea» di Lope de Vega, Il Torcoliere, Università degli Studi L'Orientale, Napoli 1998. 
masa veía marchar a la nueva Presidenta de Sala como pudiera haber visto que le llevaban la torre de la catedral, otra maravilla (I, 5, pp. 299-300).

En este sentido es significativa la referencia onomástica: Vetusta retrocede en la clasificación de población a pueblo. Un detalle importante que pone en duda uno de los bastiones de la definición de la novela como historia de provincia. La Oviedo oculta bajo el nombre de Vetusta a lo mejor ni siquiera es una ciudad de provincia, una sede cunera para la politiquería madrileña, sino una reencarnación, hasta en la oscilación de la definición geográfica, de la indeterminación del lugar de donde procede el hidalgo cervantino para sus salidas. Solo que en la recreación de Clarín en realidad no hay salidas, sino un estancamiento apático, un momento de calma que denuncia la decadencia de una clase (¿aristocrática?) resignada a una vida de burgués rentier. Quizás es esta la clave que explica y justifica la educación anglosajona de la Ozores, en donde los vestigios nobles se amoldaron a la realidad de la revolución industrial adaptándose al modelo canónico de esa: la forma de vida inglesa. Así, cuando la presencia del padre parece abrirla a la realidad que el puritanismo victoriano le había negado, esta abertura ocurre sólo bajo el signo de la mitología, abstracta y lejana, y por esto considerada, a diferencia de la novela moderna, no peligrosa según don Carlos, quien desea que la hija aprenda, como él mismo dice, a distinguir el bien del mal a través de la abstracción de un mundo cultural lejano que no le pertenece y que tampoco ella logra hacer suyo el compromiso de autodidactismo en el cual domina la precariedad intelectual. Quizás la doble previdencia social y cultural, la herencia materna, en este aspecto, puede ser interpretado como adhesión a las leyes de herencia, al determinismo positivista: para la Ozores el esfuerzo individual está forzado de manera natural por la mancha original. La virtus aristocrática sufre una prohibición por culpa de una interferencia espuria, con una sensibilidad defini- 
da romántica, de un heredero, Carlos, dañado por una ideología inconsistente ${ }^{16}$.

La prohibición implícita, inherente a la educación, en gran parte ausente recibida por el padre librepensador, de acercarse a la devoción católica termina por alejar a Ana, a causa de la inevitable desconfianza en su capacidad de autonomía, del contexto cultural en el que vive y que, entre otras cosas, es uno de los "roles" femeninos más difundidos, alentando su tendencia a vivir relacionándose con ideales abstractos $\mathrm{y}$, a menudo, tortuosos. Así, Ana descubre la religiosidad cristiana de la misma manera que descubre la sensualidad y el amor, no a través de la experiencia, sino de la palabra escrita; y es más: este descubrimiento es mediado anárquicamente por la literatura leída y recibida al azar. Es en la biblioteca paterna donde Ana encuentra las Confesiones de San Agustín, las lee por curiosidad porque bien sabe del desdén que su padre tiene hacia la religión e intuye el carácter insólito del texto, pero además tiene recuerdos vagos del rol que el amor materno, que a ella le faltó, tuvo en la conversión del noble norteafricano; de hecho, el narrador atribuye las lágrimas derramadas sobre las Confesiones "como sobre el seno de una madre" (I, 4, p. 252). A la lectura de san Agustín siguen otros textos que estimularán en ella una religiosidad patética, dirigida hacia la realización de un ideal de perfección interior que culmina en la lectura de la poesía mística de Luis de León y, luego, de Juan de la Cruz, una violación de las restricciones paternas, ya que el Cántico de los Cánticos es uno de los libros prohibidos en las casa Ozores.

El camino es paralelo a su definitiva madurez psicológica, asociada a la lectura de san Agustín ("Su alma se hacía mujer en aquel momento", ibíd.), y fisiológica ("Ella ha visto visiones...

16 Sobre el "error" de la generación romántica española, véase la novela (en parte autobiográfica) de Benito Pérez Galdós, El Doctor Centeno, de la cual me ocupo en G. Grilli, "Una maschera grottesca per Galdós: Il Doctor Centeno" en La Maschera e dintorni, curado por Gabriella Donghia, "Dialogoi. Collana di Studi Comparatistici", Aracne editrice, Roma, 2013, pp. 113-126. 
pseudo-místicas...allá en Loreto... al llegar la edad...cosa de la sangre....al ser mujercita", I, 11, p. 463), simultaneidad que en un cierto sentido comprende hasta su inmediata degradación en la ciclicidad genérica. Todo esto acompañado por el nacimiento de sus primeras perturbaciones eróticas que se manifiestan en sus rasgos físicos, la percepción sinestésica de los versos del místico en la naturaleza que lo rodea y que generan los primeros síntomas de su enfermedad nerviosa que caracterizará sus años de mujer infeliz:

Notaba Anita, excitada, nerviosa - y sentía un dolor extraño en la cabeza al notarlo -, una misteriosa analogía entre los versos de San Juan y aquella fragancia del tomillo que ella pisaba al subir por el monte" (I, 4, p. 257).

Turbada, como cualquier adolescente por culpa de una educación represiva y de la ausencia de relaciones sociales adaptadas a su edad, incapaz de dar un nombre o asignar una causa a su perturbación, y mucho menos compartirlo con alguien, Ana encuentra desahogo expresivo en la exaltación mística que ella siente similar a la suya. La búsqueda continua de protección en la lectura y escritura de inspiración místico-poética culmina en un ataque que la manda a la cama; se recupera con la ayuda del médico y el intento del alejamiento de la religiosidad sentimental. Este camino, desde la exaltación emocional hasta la lenta convalecencia, pasando por el sufrimiento físico, caracteriza el brote del instinto que primero se desplaza con un mecanismo de defensa de lenguaje y luego penetra el cuerpo a través del primer síntoma de histeria.

La exaltación mística regresa sucesivamente, después de años de sucesión afectiva y pasional junto al marido, cariñoso aunque impotente y distraído, y esta vez, por medio de la lectura de Santa Teresa de Ávila a la cual se dirige con pasión después de una larga convalecencia, víctima de repetidos ataques de ner- 
vios. En el período anterior a esta nueva condición, deseosa de no abandonar del todo la vida de la clase, pero dispuesta a seguir las órdenes de Fermín de adaptarse a una vida consagrada a una espiritualidad militante, Ana

Dividía el tiempo entre el mundo y la iglesia... Casi todos los días tenían ocasión de hablar con ella, en sus respectivos círculos, el Magistral y don Álvaro, y a veces uno y otro en el mundo y uno y otro en el templo: lugares había en que Ana ignoraba si estaba allí en cuanto mujer devota o en cuanto mujer de sociedad." (II, 19, 197-198).

El dilema de Ana es la oscilación de lo uno que pasa a ser lo otro. Oscilación continua entre estos roles de devota o dama de la clase, entre la alta sociedad vetustense y la secta que gira alrededor del Magistral; el conflicto parece enredarse entre dos absolutos, el amor y la fe, sin que logre abrazar ninguno de los dos en pleno. El primero, porque ha decidido no cometer el pecado de adulterio, el segundo porque, paradójicamente, lo recela y lo rehúye el mismo canónigo, por miedo o por prudencia, conceptos que obsesionan a la madre Paula. Quién sabe si para mantenerla anclada a la banalidad en la cual recoger el fruto prohibido. Fermín está constantemente en un equilibrio precario entre la "estrategia" del deseo loco y la imaginación descabellada del amante que, de vez en cuando se confiesa a sí mismo, cuando las defensas de la cordura se sueltan y él se autoengaña, casi fuese un novel Calisto:

«-Dirá usted que soy una loca; ¿para qué escribirle cuando podemos hablar todos los días? No pude menos. ¡Soy tan feliz! ¡y debo en tanta parte a usted mi felicidad! Quise contener aquel impulso y no pude. A veces me reprendo a mí misma porque pienso que robo a Dios muchos pensamientos para consagrarlos al hombre que se sirvió escoger para salvarme. 
El Magistral se sentía como estrangulado por la emoción. La Regenta hablaba ni más ni menos como él la había hecho hablar tantas veces en las novelas que se contaba a sí mismo al dormirse». (II, 21, p. 264).

Dicha tentación no es solo episódica, aflora a menudo y en ella se pierde, o sea resalta su naturaleza cursi:

Ana le admiraba, le cuidaba, estaba por decir que le adoraba, de tal suerte, que el peligro cada día era mayor. "Aunque la pasión que él sentía nada tenía que ver con la lascivia vulgar (estaba seguro de ello) ni era amor a lo profano, ni tenía nombre ni le hacía falta, podía ir a dar no se sabía dónde. Y el Magistral estaba seguro de que al menor descuido de la carne, intrusa, temible, la Regenta saltaría hacia atrás, se indignaría y él perdería el prestigio casi sobrenatural de que estaba rodeado. Además, suponiendo que aquello parase en un amor sacrílego y adúltero, miserablemente sacrílego por haber tenido tales comienzos, ¡adiós encanto! Ya sabía él lo que era esto. Una locura grosera de algunos meses. Después un dejo de remordimiento mezclado de asco de sí mismo; verse despreciable, bajo, insufrible, y después ira y orgullo, y ambición vulgar y huracanes en la Curia eclesiástica... - No, no. La Regenta debía de ser otra cosa. Había que hacer a toda costa que aquello no pudiese degenerar en amor carnal que se satisface. Y sobre todo, lo de antes, que la Regenta se llamaría a engaño; era seguro.» Y después de una pausa, pensaba el Magistral: «Y en último caso, ello dirá.» (II, 21, p. 285).

De Pas, en este punto comete el error que lo pierde definitivamente a los ojos de Ana: la motiva a efectuar ejercicios espirituales de devoción irrisorios que la aburren y la desilusionan ${ }^{17}$.

17 Ed. Oleza, I, 302: «¿para qué engañarse a sí misma? No estaba en Vetusta, no podía estar en aquel pobre rincón la realidad del sueño, el héroe del poema, que primero se había llamado Germán, después San Agustín, obispo de Hiponax después Chateaubriand y después con cien nombres, todo grandeza, esplendor, dulzura delicada, rara y escogida...». "Y ahora estaba casada. Era un crimen, pero un crimen verdadero, no como el de la barca de Trébol, pensar en otros hombres. Don Víctor era la muralla de la China de sus ensueños. Toda fantástica aparición que rebasara 
Paradójicamente esta diferencia, la determinación misma de pertenecer a un segmento definido y separado del mundo social, la absorbe, como sucede, ex contrario, en el capítulo IX, donde el pueblo, o sea esa parte que se asemeja al proletariado urbano, en que la melancolía de la miseria (la misère de "los franceses" posterior al éxito de Les Miserables, postrománticos) se le acerca $\mathrm{y}$, por instinto y sensiblería hacia lo hermoso, la elige, por un efímero relámpago, heroína de los desheredados:

En Vetusta la juventud pobre no sabe ganarse la vida, a lo sumo se gana la miseria; muchachos y muchachas se comen a miradas, se quieren, hasta se lo dicen... pero lo dejan; falta una posición; las muchachas pierden su hermosura y acaban en beatas; los muchachos dejan el luciente sombrero de copa, se embozan en la capa y se hacen jugadores. Los que quieren medrar salen del pueblo; allí no hay más ricos que los que heredan o hacen fortuna lejos de la soñolienta Vetusta ${ }^{18}$.

Lo que la Ozores busca es algo que la absorba completamente y saque su vida del sentido de inutilidad que la invade desde hace demasiado tiempo. Algo que no puede obtener en Mesía y tampoco encuentra en el ejemplo de vida devota de las demás beatas de Vetusta. Como siempre, es palpable la incapacidad de la Ozores, cerrada en su penoso y narcisista autoanálisis originado en la soledad de la infancia, de comprender la realidad que la rodea más allá de sus proyecciones y fantasías. Reconocer, en las presiones que ejercen dos hombres comprometidos, una guerra para obtener el pleno dominio sobre ella, la mujer más vista de la ciudad, la enorgullece, pero la aísla. Pues se trata de una lucha que expresa no sólo (no tanto) el interés erótico y sentimental de ambos hacia ella, sino una verdadera rivalidad entre dos

de aquellos cinco pies y varias pulgadas de hombre que tenía al lado, era un delito. Todo había concluido... sin haber empezado». 
formas de afirmación social masculina. Alfani afirma, «tanto para Fermín como para Álvaro la conquista de Ana funciona a la confirmación de un prestigio social (y político) que empieza a vacilar en el microcosmos de Vetusta.» ${ }^{19}$. Obviamente para Ana la perspectiva era muy diferente. El misticismo de Ana Ozores está asociado a su histeria, y, según muchos estudiosos, es la concausa junto a la represión de la propia sexualidad, de su indecisión comportamental ${ }^{20}$. A este respecto Oleza comenta:

Los intentos desesperados de Ana de emancipar su vida espiritual de la vida material que la rodea (Vetusta) o de los condicionamientos de su propio cuerpo (sobre todo los eróticos), la conducen inevitablemente a la histeria y a la prostación física (II, p. 178, nota 11).

El lenguaje de la literatura mixta, con sobre posición de léxico y acentos sobre la pasión carnal a la visión contemplativa de Dios, constituye una válvula de desahogo para el deseo, de una manera alternativa, aunque ineficaz, a la histeria. Se trata de otra manera de "expresar" el propio desapego sin que se violen las reglas sociales. En este modo se ofrece un acceso al erotismo a través del lenguaje del misticismo que, en esta fase de la vida espiritual y erótica de Ana, sigue un camino de evolución diametralmente opuesto al que se manifestó con la pubertad. Mientras de adolescente la exaltación religiosa precedía una enfermedad física, de adulta, con el acercamiento al libro de Santa Teresa, ocurre lo contrario: llega durante un período de larga estadía hospitalaria, que viene después de una violenta noche devastada por el delirio histérico.

En fin, el misticismo es para Ana Ozores un desplazamiento inconsciente de su frustración, un modo para acceder a la di-

19 Alfani, op. cit., p. 41.

20 Entre otras referencias, señalo a Joan Ramon Resina, "Ana Ozores's Nerves", Hispanic Review, 71, no. 2, Spring 2003. 
mensión erótica a través del escudo del lenguaje y la excitación del espíritu, eludiendo la barrera que la respetabilidad burguesa opone al deseo por medio del control de su cuerpo. Que la contemplación sea una especie de experiencia erótica (memoria vaga de aquel lejano amor hereos o heroicus de la Baja Edad media $^{21}$ ) que elude el control de la moralidad burguesa, se confirma en la inquietud que provoca el marido de Ana, quien reconoce que hay un obstáculo a su felicidad doméstica. Hasta llegar a afirmar que preferiría saberla entre los brazos de otro, territorio en el que piensa que puede ejercer sus propias prerrogativas de dominio masculino y la autoridad de marido, más bien que verla ensimismada en una exaltación en la cual él no tiene ninguna posibilidad de intervenir, ya que sus derechos matrimoniales se limitan al control del cuerpo y la sexualidad femenina, como a menudo confesará Ana, reflexionando sobre su condición de esposa infeliz.

Sin embargo, ella toma plena conciencia de este carácter sensual del misticismo solo en el momento en que enfrenta la suprema prueba de la procesión cuando desfila descalza durante el viernes de Pasión. Ese momento representa el apogeo de su ensimismamiento religioso junto al sincero aunque exaltado compromiso a la pasión sentimental compartida con De Pas y, a la misma vez, la desilusión y desengaño de esa ilusión. Es la fase en que, resignada más bien que enamorada, consumará el adulterio con Mesía. El lenguaje con que Ana expresa sus tardías perplejidades respecto al gesto que está por cometer es considerable por su asimilabilidad a la idea de infidelidad, ya que el gesto se cumple para manifestar públicamente su propia sumisión a la dirección espiritual de don Fermín, aun sabiendo que le causa un dolor y deshonor al marido:

21 Por ejemplo recuérdese el impacto que estas concepciones médicas habían tenido en la literatura, en particular en La Celestina; cf. Bienvenido Morros, " $\mathrm{Me}$ lancolía y amor hereos en La Celestina", Revista de poética medieval, n. 22, 2009, pp. 133-184. 
Lo deseaba y le remordía la conciencia de este deseo. Estaba asustada de su propia obra. ... Ana pensaba también en su Quintanar. «... ¿No iba a estar en ridículo aquel marido que tenía que ver a su esposa descalza, vestida de morado, pisando el lodo de todas las calles de la Encimada, dándose en espectáculo a la malicia, a la envidia, a todos los pecados capitales, que contemplarían desde aceras y balcones aquel cuadro vivo que ella iba a representar?»... no pensaba más que en el escándalo de aquella exhibición. «Sí, escándalo era; la mujer de su casa, la esposa honesta, protestaba dentro de Ana contra el espectáculo próximo...»" (II, 26, p. 418; i la cursiva está en el texto).

La escena se caracteriza por un marcado voyeurismo de los habitantes de Vetusta que, en manera fetichista, se concentran en los pies de Ana, y como ella misma percibe son sinécdoque de su desnudez: «Aquellos pies desnudos eran para ella la desnudez de todo el cuerpo y de toda el alma» (II, 26, p. 424), suscitando pensamientos y deseos mal reprimidos sobre todo por la atmósfera de sadomasoquismo que permea el espectáculo de la mujer más hermosa y admirada de la comunidad ofrecida a la mirada del vulgo, humilde y vulgar a la misma vez. Sensación que bien intuye Obdulia, experta seductora, maestra en exponer su cuerpo a la admiración masculina y derrotada también ella por un impulso hacia la mujer hermosa humillada, "esto es cuestión de escenario" (II, 27 p. 448, la cursiva está en el texto). Por otra parte en Obdulia reina la tentación autoerótica y subrepticiamente homosexual. La aceptación de Álvaro por parte de Ana Ozores, no es la entrega a la transgresión, sino más bien el intento de amoldarse a la normalidad.

Asustada y turbada, Ana se retira de los excesos del Magistral, intuyendo cuánto la atracción por el poder prevalece sobre la pulsión espiritual y sentimental y bajo la égida del joven doctor Benítez, se encamina a superar las crisis periódicas. El joven médico, abierto a las nuevas teorías, es el único que logra penetrar el secreto de la enfermedad histérica que aflige a la Regenta, y que Somoza, el anciano médico de Vetusta que hasta aquel momen- 
to se había ocupado de ella, desconocía en sus manifestaciones clínicas. El doctor Benítez encarna la figura del "confesor moderno" que investiga los enlaces entre la psiquis y el cuerpo, que aspira a reunir lo que la cultura de la oposición entre carne y espíritu había separado arbitrariamente como, con tanta agudeza, observa Cerrón Puga en su ensayo basado en las dinámicas de la confesión de la novela. El tratamiento funciona, Ana recupera un cierto grado de salud psicofísica que no es curación, como quisiera Quintanar, sino una mejoría de los síntomas sin resolución del problema, como admite el mismo médico. Ni el misticismo, ni la histeria regresarán por un cierto período de tiempo a atormentar a Ana, el primero eliminado por la humillación de la prueba a la que le había sometido Fermín en un arrebato pasional, la segunda por el abandono a la entrega en la práctica del adulterio. Las dos experiencias la sacan del círculo vicioso de sus idealizaciones, que representan, a pesar de la aparente voluntariedad de sus decisiones, el punto extremo de sumisión al cliché predefinido en una sociedad que se somete a una rígida representación de roles preestablecidos. Al final, sin embargo, el triunfo de Mesía es tan efímero como el de De Pas.

Naturalmente a ese extremo o punto de crisis y climax narrativo, ni se llega de golpe, ni tiene su explicación solo en el plano psicológico. Su imbricación con la general sociológica vetustense es decisiva y concomitante. $\mathrm{Al}$ respecto cabe entender la paulatina evolución en la combinatoria de roles y de designaciones personales e interpersonales. El anti-magistral es, a la vez, el "precedente" histórico del parvenu De Pas. Don Gayetano, ya confesor de Ana Ozores antes que él mismo la confíe a don Fermín, fue un seminarista con atisbos de abatino neoclásico. Su actitud, si fuera algo más culto y sobre todo si no estuviese encogido en la estrechez del ambiente que le rodea, provinciano y materialista, iría con cierto vigor a tantear una colocación poética o literaria seria. Pero a falta de pan, buenas son tordas y el Arcipreste logra identificarse con algo que, en otro lugar y en otro momento, sería una medianía programática: 
No era liberal ni carlista. Era un sacerdote.» La juventud le atraía y prefería su trato al de los más sesudos vetustenses. Los poetillas y gacetilleros de la localidad tenían en él un censor socarrón y malicioso, aunque siempre cortés y afable. Encontrábase en la calle, por ejemplo, con Trifón Cármenes, el poeta de más alientos de Vetusta, el eterno vencedor en las justas incruentas, de la gaya ciencia; le llamaba con un dedo, acercaba su corva nariz a la ancha oreja del vate y decíale:

- He visto aquello... No está mal; pero no hay que olvidar lo de versate mane. ¡Los clásicos, Trifoncillo, los clásicos sobre todo! ¿Dónde hay sencillez como aquella:

Yo he visto un pajarillo

posarse en un tomillo?

Y recitaba la tierna poesía de Villegas hasta el último verso, con lágrimas en los ojos.

La distribución ideológica de la clerecía vetustense tiene un relieve grande, siendo importante su actuación en la vida urbana. Si se ha podido considerar la vida de la Catedral como la esencia misma de la sociedad política de la urbe, la diseminación y dislocación de los protagonistas de este estamento o supervivencia estamental en una fingida realidad social moderna, hay que considerarla definitoria. La verdad, sin embargo, viene determinada por la paradoja de estar don Goyetano aislado en el gremio, a la vez que sería, podría ser, la figura más cercana al talante del Arzobispo, don Fortunato, quien en cambio queda atrapado en las garras dialécticas (o pseudo ideológicas) del Magistral y otros de la misma ralea. Véase ese pasaje que, como en muchos otros casos de decriptio sociológica de la novela desarrolla el discurso paradójico:

Fortunato era un santo alegre que no podía ver una irreverencia donde se podía admirar y amar una obra de Dios. 
Glocester, el maquiavélico Arcediano, «opinaba que el Obispo - pero éste era su secreto- no estaba a la altura de su cargo.»

«-No basta ser bueno - decía - para gobernar una diócesis. Ni los poetas sirven para ministros, ni los místicos para Obispos.»

Esta opinión era la más corriente entre el clero del Obispado. Los señores de la junta carlista creían lo mismo. ¡Jamás habían podido contar para nada con el Obispo!

¿Qué resultaba de aquella excesiva piedad? Que S. I. se abandonaba en brazos del Provisor para todo lo referente al gobierno de la diócesis. Esto, según unos, era la perdición del clero y el culto; según otros una gran fortuna; pero todos convenían en que el bueno de Camoirán no tenía voluntad.

De ello se desprende que en realidad la política de la Catedral sea, de hecho, secuestrada y roída por la sugestión carlista y que esta opción conviva con la aristocracia de adhesión liberal al régimen de Madrid, si bien se manifieste cierta rivalidad de superficie. La lucha de Álvaro Mesía, diputado adscrito al partido liberal monárquico, y don Fermín De Pas, integrista aliado con los carlistas, por la posesión del cuerpo y alma de Ana Ozores, que hemos visto desde el mismo exordio de la novela, identificada con la ciudad y, luego, explícitamente, adjudicada como museo viviente y gloria idiosincrática de toda Vetusta. Me parece significativo que al final ambos agresores de lo bello, sin llegar verdaderamente a comprenderlo, huyan delante de la Regenta, y hundan a la misma Ana Ozores en una soledad sin pausa ni remisión. La vuelta al Museo, la mineralización de sus impulsos humanos y eróticos es la demostración de la esterilidad de ambas elecciones ideales y políticas de la Vetusta eterna e inútil. El intento de animar un contexto durmiente, aunque emprendiendo e interpretando la apática revuelta señalada por el subgénero de la novela de adulterio, no da resultado alguno. Ni un suicidio grotesco, como en el modelo arquetípico de Emma Bovary, ni una tragedia sentimental y legal, como en Fontane y Herzen, podrán ofrecen un rescate a Vetusta y darle un toque novelesco, una 
emoción melodramática: solo la patética remisión de Quintanar puede vislumbrar algo, y ese algo se acerca mucho, tal vez demasiado, a una combinación entre el sainete y la zarzuela. Ambos géneros menores. Pero en esta adhesión deliberada a celebrar el triunfo de lo pequeño, Leopoldo Alas Clarín ha conseguido su obra maestra, il capolavoro.

En el epílogo de la novela se representa el ocaso de la literatura y la religión como puntos de referencia para la constitución de la identidad. El matrimonio con Quintanar había sido para Ana la realización de un estatus de bonanza económica y vital, pero también, su pronta decadencia, con consecuente caída en el ideal burgués. En este esquema comportamental el enlace está fundado sobre sentimientos de mutua estima y consideraciones de conveniencia, en la que la absoluta castidad de la mujer no se pone nunca en discusión, hasta el punto de que el marido se abstiene de tratar al ángel del hogar como a una amante, prefiriendo dirigir las propias atenciones, efímeras y sin consecuencias, hacia cualquier objeto más humilde, o supuesto como tal. Y Alas confía este papel a camarera la Petra, determinando otra paradoja del relato. La unión de los Quintanar tiene, respecto al ideal de la familia burguesa, el defecto - para nada secundario y transmutable -, de no dejar herederos, un peso ingente para Ana, un ulterior elemento ausente para la construcción de su identidad según las prescripciones de la sociedad a la que pertenece, o debería pertenecer, si esta sociedad existiera de verdad y no fuera una prolongación falsa de un engaño originario, artefacto consecuencia de la mala educación adquirida, de la mala literatura o en todo caso de una literatura mal leída.

La relación con Mesía, que debería realzar lo novelesco, la fuga de las constricciones de su realidad cotidiana, acaba en otro arrebato artificioso y vano. El retorno consecuente a la Catedral y a su mentor, De Pas, después de la fuga innoble del amante incongruo, y el gesto imperioso con el que el canónigo la rechaza, dictado por el resentimiento, es ulterior manifestación de la miseria ambiental, proclama la pérdida de una añorada, jamás 
adquirida, identidad superadora de la estrechez de la identificación del género. Y aquí con género se alude tanto al rol de la mujer, como a la estructura de la novela.

En la imagen final de la histérica Ana Ozores que vuelve en sí después de haberse desmayado en la oscuridad de la catedral con la sensación del insidioso beso de Celedonio, el acólito afeminado, encarnación de sus pesadillas histéricas, se abre paso a un dominio nuevo para la definición de la mujer a finales de siglo: el siglo de la nueva medicina positiva, o sea de la psiquiatría primero y luego del psicoanálisis, el territorio donde destaca el doctor Benítez, que cita los estudios más recientes sobre las enfermedades nerviosas y experimentos sobre la histeria de Charcot y sus colaboradores en la Salpetrière, un médico que escucha y observa, silencioso y frío, a su paciente, esperando que su cuerpo y lenguaje le entreguen el secreto de su enfermedad. Sin embargo tampoco la ciencia nueva tiene esa receta resolutoria y a lo más alcanza a ser lenitiva. La cura acaba por enclaustrar a Ana en una agria soledad recalada en el fondo en un único interlocutor, Crespo-Frígilis, quien fraguó su matrimonio y acompañará finalmente su viudez.

Alas escribe, a pocos años de la maduración de un siglo, una novela que proviene de la moda y práctica del subgénero del adulterio, enfrentando - en manera diversa de los de la proyectualidad positivista y determinística - la afirmación de la histeria como categoría de definición de lo femenino, y, a través de la metáfora de género y la figuración de género, un elemento que proyecta la novela hacia el reconocimiento de la fragmentación del yo. Con esto Ana Ozores ya está fuera del esquema del cuento de (y sobre) el adulterio. Y puede ubicarse, sin limaduras, en el laberinto de la modernidad.

\section{Ana y Petra, Petra y Ana}

El punto de auténtica definición (o de eclosión) en el análisis de la construcción de la identidad de género y las dinámicas in- 
terpersonales, con precisa referencia a la interconexión del sexo y la pulsión sexual, en el interior del texto de la novela-obra maestra clariniana, resulta obviamente el de un personaje femenino que, en manera más evidente que en otras manifestaciones coevas, pone en discusión los roles predeterminados del personaje del siglo XIX, obsesivamente atados y obligados a la equivalencia social. Esta es tan determinante en la dispositio de los episodios y en la descriptio de las situaciones, aunque de por sí no es suficiente a hacer homogéneo y significativo el desarrollo de las estrategias narrativas y estilísticas. Ana Ozores permanece siendo el pernio de la novela, y en dicha bisagra es posible hallar los rasgos portantes de la estructura, o macrometáfora, de la obra maestra clariniana, pero el autor coloca a otra de las figuras femeninas del libro, a sabiendas desplazada en una dimensión de semi marginalidad, aunque luego se descubre, poco a poco, su centralidad tanto en el plano de la definición psicológica como literaria, y ésta - come hemos ya avanzado - es Petra. La doncella, destinada al servicio exclusivo de Ana Ozores, lo que debería asegurar a la Regenta una condición aristocrática que, en los demás aspectos, se reduce a la jaula atributiva de mujer burguesa gradualmente expuesta a ajamonarse. En efecto, en este sentido, su aumento de peso, sus formas redondeadas, su paz emocional son índice por un lado de la mejoría de salud física y mental, por otro de su regresión como objeto accesible al deseo masculino, ya no solamente espejismo hiperbólico inalcanzable. El máximo exponente de esta transformación material, que se convierte en simbólica, es su liga roja, que transmigra, de la heroína protagonista originaria, a sujetar las medias de la joven mujer que se afirma en el momento que aspira a más, y así se autoexcluye y margina en un espacio fuera del tiempo y de cualquier condición histórica. Petra ni engorda ni mengua y puede perfectamente ponerse una prenda - casi garcilasiana: dulces prendas por mi mal halladas... - que había pertenecido a Ana y que, en virtud de su largo exilio (diez años, evocarán al final Frígilis y Quintanar "no son pocos..."), resultando casi in- 
útil. Petra permanece fuera de la asimilación con el sufrimiento obrero, solo por un instante siente atracción por la menestralía interpretada por el primo artesano, y en todo caso está fuera de lugar en el mundo de los nobles verdaderos, o falsos ${ }^{22}$.

Por otro lado, Petra es la única que beneficia de un "estilo", incluso lingüístico, característico, aun cuando denotado en términos negativos ${ }^{23}$; el personaje resulta determinante en establecer el cierre de la novela y su desenlace de la acción, indudablemente grotesca, en el que todos los personajes principales reciben una afrenta. Se trata de la doncella, que es, como se ha mencionado anteriormente, término abusivo e hiperbólico para indicar a la camarera personal de Ana Ozores ${ }^{24}$. Petra es la figura hábilmente ilustrada, quizá mejor que cualquier otra, por Leopoldo Alas, quien probablemente se basó en un modelo vivo. Su aparición en la narración se traza gradualmente, sin énfasis aparente, como si su presencia no tuviera particular importancia en la economía del texto, mientras luego, poco a poco, adquiere importancia siempre manteniéndose en los márgenes -, entre los pliegues del cuento. Es cosa resabida y reconocida por la crítica que Petra es el carácter inductor que acelera los sucesos del final, pero en realidad su presencia alternada en momentos que solo a posteriori reconoceremos decisivos, se hace explícita en el desenlace. Basta recordar que es ella quien le permite a la estrella Ozores la

22 Lo demuestra el fracaso del paseo con el Marquesito Vegallana, en duetos con la primera pareja, formada por Ana Ozores y Álvaro Mesía: «Petra ya estaba dentro, en el patio, haciendo como que no oía. "Ya sabía a qué atenerse; era aquél. Por lo menos aquél era uno. El Marquesito la había entretenido a ella para dejar solos a los otros. Se le conocía en que estaba tan frío. No le había dado ni un mal abrazo en lo obscuro» (Ed. Oleza, I, 9, p. 432).

23 Lo notó Claudio Guillén, "Apuntes para un estudio de la diégesis en La Regenta", en Antonio Vilanova (ed.), Clarín y su obra en el centenario de la Regenta, PPU, Barcelona 1985, pp. 265-291; la nota se encuentra la p. 289. Guillén luego ha sido asimilado y repetido por Gargano casi integralmente (cf. G. Grilli, Cronache del disamore, cit., p. 104).

24 Ver la nota 12. 
única apariencia de iniciativa con la jira fuera de la ciudad y el regreso a la ciudad a través de las calles con los escaparates, los muchachos, y los obreros, o sea del mundo real donde vibran las voces, acentos y tonalidades de la lengua no convencional de las mansiones encerradas de la aristocracia provincial y la clerecía catedralicia. Es también Petra protagonista en la deportación al Vivero de los conflictos y es la ella que resulta capaz de captar la naturaleza ficticia de una fábula pastoral apócrifa que revela con la parodia de uno de los mitos fundamentales de la nobleza de fines de la edad media: el mito/orden de la liga, la orden de la Jarretera ${ }^{25}$. La liga roja, regalo de Quintanar a la esposa, acaba abandonada en la cabaña donde la doncella ha consumado un orgasmo apresurado con el ingenioso (lo es holgadamente en banquetes y fiestas, donde cree estar a sus anchas) e incongruo Magistral, que al final se revela mal amante, casi recuerdo del anciano hidalgo cervantino en la aventura de Maritornes. Una escena en la cual destaca el detalle: Petra viste el traje de aldeana que no es fácil de quitar para un abrazo rápido. Pero Petra ya había estado presente, con creces, en el medio de la crisis histérica de mayores consecuencias que había afligido a Ana Ozores, presa del palacio-prisión, un Palacio en el cual la encierran primero como Ifigenia, y luego confinarán como lúbrica Pasifae. Y, en aquella circunstancia, Petra muestra a su marido (de Petra), el candor de sus carnes palpitantes, tórridas, síntoma de una juventud que reta al frío del caserón, espécimen trivial, deliberadamente trivial, de la misma frialdad del amo. Un patrón jubilado, vista la lejanía de su señorío en Aragón, en donde es dueño de una considerable extensión de tierra seca, de secano, no productiva. Ahora, Quintanar aparece privado incluso de la reconversión burguesa, ya que la Audiencia de la cual era Regente, lo ha puesto

25 Nótese que se trata de esa famosa orden caballeresca creada por el rey de Inglaterra en el curso de una célebre fiesta con baile histórica y celebrada por Martorell en su extraordinario libro del Tirant lo Blanch; remito para el episodio a mi Del Tirant al Quijote, "Dialogoi-Ispanistica", Aracne, Roma 2014 (reedición de volumen de 1994, en Adriatica editrice). 
fuera de juego y fuera de todo rol, por límites de edad: la jubilación le permite el arte venatorio con una sombra del galgo corredor que fue el mayor privilegio del hidalgo de la Mancha antes de enloquecer completamente ${ }^{26}$. Petra, en virtud de su dinamismo, que se exterioriza en la fugacidad de sus entradas en escena y de sus salidas, escondiéndose o simplemente desapareciendo en el fondo, o por una puerta que se entreabre de la misma manera que se había abierto casi repentinamente. El detalle - este de la puerta - nos conduce al momento de su denuncia, repentinamente: su irrupción en el cuarto de De Pas, después de haber descubierto la inutilidad de su silencio acerca de la relación entre su ama y Mesía, o sea de la inutilidad de su silencio para proteger el mundo de esos señores que reconoce como señores ridículos, partidos en dos. Siguiendo un impulso súbito, aunque también meditado y voluntario, como siempre en ella, Petra sugiere una alternativa posible al comportamiento de la protagonista. A la abulia, a la paz de los sentidos -Alas define el arrebato erótico de Ana Ozores envuelta en "una nube de opio" - la revuelta extrema y vana. Como corolario de una tesis acerca de la inutilidad, o sea imposibilidad de toda revolución, desde la carlista del príncipe Carraspique $^{27}$, a la integrista del Magistral, hasta la ateística de

26 Miguel de Cervantes, Don Quijote de la Mancha, al cuidado de Silvia Iriso y Gonzalo Pontón, Galaxia Gutemberg, Barcelona 1998, p. 111: (...) un hidalgo de los de lanza en astillero, adarga antigua, rocín flaco y galgo corredor».

27 Es significativo que Alas asimile a la revuelta carlista que agitó la península prácticamente durante un siglo y medio (hasta englobar la intervención requetés en la guerra de los tres años (1936-1939) un rol casi ridículo ejemplificándolo en el personaje de Carraspique: «Don Francisco de Asís Carraspique era uno de los individuos más importantes de la Junta Carlista de Vetusta y el que hizo más sacrificios pecuniarios en tiempo oportuno. Era político porque se le había convencido de que la causa de la religión no prosperaría si los buenos cristianos no se metían a gobernar. Le dominaba por completo su mujer, fanática ardentísima, que aborrecía a los liberales porque allá en la otra guerra, los cristinos habían ahorcado de un árbol a su padre sin darle tiempo para confesar. Carraspique frisaba con los sesenta años, y no se distinguía ni por su valor ni por sus dotes de gobierno; se distinguía por sus millones. Era el mayor contribuyente que tenía en la provincia la soberanía subrepticia de don Carlos VII» (Ed. Oleza, I, 12, p. 490). 
Guimarán. Como ya he dicho en otra parte «Petra funciona como pegamento erótico de los tres protagonistas masculinos de la novela, a modo de simulación, o segunda oportunidad, respecto a la función ejercida por Ana» ${ }^{28}$. Como tal representa la conciencia erótica, en el sentido original de la macrometáfora, que falta a su imagen referencial falsamente dominante y es ella para el lector, en relación a las dinámicas sexuales entre Ana y los tres hombres que la rodean, el punto de vista competente que no puede ser el de la protagonista. Porque es precisamente en la erótica, en su metáfora poética, $\mathrm{y}$, a la misma vez, ahora en su redefinición narrativa, en la que estriba el sentido de la verdad del mundo, o al menos de su verdad inteligible y narrable.

Ana, completamente absorbida por sus dudas y debates internos, posee siempre una visión deformada de los demás personajes y eventos que ocurren a su alrededor. Petra, que siempre está a su lado, es la conciencia, la mirada clara, aunque a menudo maliciosa y cínica en su desengaño ${ }^{29}$, finalmente, logra anticipar los eventos que implicarán a la Regenta. Ella posee esa experiencia que la educación represiva ha negado a Ana, tanto que entre las dos se instaura muy pronto un antagonismo tieso y tácito, una competición, con la Regenta, irritada por la familiaridad con la que la trata la joven camarera, y la otra, decidida a demostrar su superioridad respecto a la otra, a pesar del estatus social, en inteligencia y penetración psicológica, pero también en capacidades de seducción, vital.

28 G. Grilli, Cronache del disamore, cit., p. 102 ("Petra agisce come collante erotico dei tre protagonisti maschili del romanzo in una sorta di simulazione, o seconda opportunità , rispetto alla funzione svolta da Ana").

29 «Petra se encerraba en su cuarto. Colgada de un clavo a la cabecera de su cama de madera tenía una cartera de viaje, sucia y vieja. Allí guardaba con llave sus ahorros, ciertas sisas de mayor cuantía, y algunos papeles que podían comprometerla. De allí sacaba el guante morado del Magistral, del que a nadie había hablado. Era una prueba, no sabía de qué, pero adivinaba que sin saber ella cómo ni cuándo, aquella prenda podía llegar a valer mucho» (II, 21, p. 269). 
Mucho antes de que Ana ponga en duda la propia capacidad de resistencia a la tentación representada por don Álvaro, cuando estaba segura de la defensa a ultranza del peso de su marido como propio, concediéndose al otro (que no es en absoluto el otro sino una simulación, una máscara insinuada de lo idéntico), se encarna y se identifica diversamente en la histeria, pero similarmente en la representación de la enfermedad, desplegando sus impaciencias que ahora están dirigidas a elevar el espíritu del tormento del deseo, que sabe vagamente, inconscientemente, destinado a permanecer insatisfecho. Petra intuye, por un simple capricho del ama que era el inicio de un recorrido, por lento que pareciera, hacia el adulterio. El episodio es significativo porque sigue la primera confesión de Ana con Don Fermín, una confesión como un río, escandalosa por duración e intensidad, memorable en toda Vetusta por la excepcional duración que por cada pasaje de boca del cotilleo se alargaba cada vez más. En ese escándalo, replicado y banalizado en la procesión descalza, la Regenta se siente fuerte, optimista e ilusionada de haber encontrado en el nuevo confesor a alguien que ella juzga a la altura de comprenderla: encuentra en el desierto social que para ella es la pequeña provincia de Vetusta, un interlocutor. Pero se trata de un interlocutor inepto, otro culto a medias, otro figurón de zarzuela. De vuelta a casa, frente al portón del edificio de los Ozores, la bella siente un deseo de aplazar su regreso y, deseosa de seguir los propios pensamientos en soledad, insiste en que Petra la acompañe a dar un paseo por el campo húmedo del atardecer ${ }^{30}$. La reacción de esta última no deja lugar a dudas de la importancia de Petra, que destaca - como hemos dicho - por primera vez íntegra e imperiosa:

30 Es el episodio del capítulo IX al que ya me he referido. A este capítulo se refiere Alarcos Llorach, "Notas a La Regenta", pieza cabal de ese número monográfico de Archivium, ya mítico (II, 1 -1952-), pp. 141160, donde señala la técnica con esa frase de "dos pasos adelante y uno atrás" (p. 151) de la cual parte mi lectura (cf. mi Cronache del disamore, cit., p. 135, para la captación del concepto alarquiano de temporalidad). 
Un paseo a campo traviesa, después de confesar, solas, en una tarde húmeda, daba mucho en qué pensar a Petra. Ella no deseaba otra cosa, pero insistía en su oposición por ver adónde llegaba el capricho del ama. Otras habían empezado así. (I, p. 419)

Mientras Ana se pierde en el recuerdo de la confesión, Petra llega hasta el molino de su primo Antonio con el cual vive una relación saltuaria con la intención de casarse con él en un futuro no tan lejano. Es una duplicación de la escena de jira en barco de Ana con Germán cuando niños y que se reproduce en los términos eróticos que habían sido atribuidos erróneamente: el sueño infantil de ser marido y mujer contra el proyecto de realizarlo, la ignorancia completa e inocente contra el pleno control. La ausencia furtiva, el encuentro clandestino de su doncella conllevan para Ana una serie de humillantes preguntas inquisitorias referidas a un pasado falso y frágil, a las que su inocencia no había sabido responder. La misma actitud inquisitoria estalla en ella frente al aspecto desordenado de la camarera, que sostiene la mirada y la desafía, huyendo así del mecanismo de comportamiento de culpabilidad de sí y de la sexualidad a la cual la otra trata de someterla. La clave del comportamiento de Petra reside en la conciencia de sí y de la propia sexualidad que Ana no poseía de niña, pero que, como hemos visto, como consecuencia de la herida por las humillaciones consecuentes a su inocente amistad con Germán y al matrimonio sin amor con Quintanar, se rehúsa a tener en la edad adulta. Esto constituye la humillación que le impide albergar el conocimiento del placer durante la luna de miel, una afrenta a sus aspiraciones ideales, a su anhelo de algo supremo y que, en el prosaísmo de la unión con un hombre que no ama, le revela no lo que es la sexualidad, sino lo que debería ser, haciéndole sentir el peso de una condición de mediocridad y compromiso a la cual la firme voluntad de ser esposa fiel no le permite huir, aunque luego esa promesa de fidelidad se transforma en la excelencia alcanzable. Una excelencia a que, tras diez años de abstinencia, la alianza entre lo físico y lo moral, le im- 
pone renunciar. La orden perentoria del cuerpo en la crisis de la edad, cuando ya se insinúa el declive, y la resignada constatación que ser distinguida es inútil frente a una Vetusta permanentemente en siesta, le imponen ser como todas las otras.

El episodio del molino, interpretado a la luz del episodio del barco, tiene un valor específico en la relación que el texto establece entre Ana y Petra. De mayor consecuencia, tanto para la trama como para la comprensión "en negativo" de la Regenta a través de Petra, son las relaciones que esta última instaura con Quintanar, Mesía y Don Fermín y que hacia el final de la novela la vuelven el único personaje que conoce las intrigas de todos y por lo tanto puede dirigir la evolución de los acontecimientos, control por lo que está feliz y satisfecha: "Petra era feliz en aquella vida de intrigas complicadas de que ella sola tenía el cabo." (II, 29, p. 509). Del marido de Ana, la pelirroja camarera conoce la impotencia y la falta de seguridad que lo llevan a renunciar a todo impulso eróti$\mathrm{co}$, que no le falta, aunque se manifiesta más como adhesión al rol que a las solicitudes del deseo. Ana está convencida que el marido la descuida por absoluto desinterés y frialdad involuntaria, que lo transforma pronto en una figura paternal y afectuosa, también porque ella no logra decir a Quintanar su avidez, ya que sabe, tristemente por haberlo experimentado, y el mismo Quintanar expresa, y confiesa nada menos que a Álvaro, como «en el momento crítico me falta el valor» (II, 28, p. 496) ${ }^{31}$. La camarera, al contrario, sabe de los ocasionales impulsos eróticos del magistrado, quien no desdeña su actitud espontáneamente seductora, pero conoce también su incapacidad de darle seguimiento y la tendencia a resolver la tensión erótica en miradas y palabras, soslayando las acciones ${ }^{32}$.

31 Por ello es patético su acordarse de Petra justo en el momento que su destino está derrumbándose definitivamente: «Suspiró don Víctor. Se alegraba en el alma de verse libre de aquel testigo y semi-víctima de sus flaquezas; pero, así y todo, al recordar ahora que en vano gritaba «iPetra!» sentía una extraña y poética melancolía. « ¡Cosas del corazón humano!»: véase al respecto la nota siguiente.

32 El particular de un Quitanar algo caricaturesco en su actitud de semi-enamorado de Petra (tal vez porque semi-enamorado de Ana) fue notado muy opor- 
En el caso de la relación con Fermín, es ella (Petra) la que toma la iniciativa frecuentando con insistencia el confesional suyo, antes de que el ama se haga su hija espiritual y hasta el momento en que el canónigo la aleja, porque ocupado en la dirección espiritual de mujeres de clase social más elevada y no quiere verse comprometido por el comportamiento procaz de la muchacha. Cuando se presenta la ocasión de un encuentro clandestino, es ella la que gestiona la situación, sugiriendo el lugar y la oportunidad sin dejar de alentar a don Fermín con elogios muy precisas sobre sus características físicas que su traje sacerdotal parece mortificar:

-No, que es usted fuerte no necesita decirlo: bien a la vista está (II, 27, p. 458).

\section{$(\ldots)$}

¿Cansado? ¡bah! - se atrevió a decir - un mozo como usted. (II, 27 p. 458).

Petra tiene dos motivos para aceptar las atenciones que ella misma solicita: tomar el lugar de Teresina como camarera en la casa De Pas, pasaje que llevaba a la asignación de una propiedad, bajo forma de dote matrimonial, en el momento de casarse, y triunfar así otra vez sobre la Ozores que por que sabe, por la prisa y superficialidad de la relación tenida con Fermín, que puede ejercer una atracción fatal en el canónigo. Los mismos sentimientos de rivalidad animan su relación con Mesía, contemporánea a

tunamente, y con agudeza, por Emilio Alarcos Llorach, "Aspectos de la lengua de Clarín (un pasaje de La Regenta", en el escrito con el que se abre el volumen Clarin y su obra en el centenario de la Regenta, al cuidado de Antonio Vilanova, cit., pp. 13-30; la caracterización del regente halla su climax justo cuando él está a punto de caer en la trampa urdida por la misma Petra que le causará la muerte: mediante el detallado análisis lingüístico se pone de manifiesto lo patético y lo grotesco de don Víctor llamando compañía en la soledad de un despertar anticipado que él no se explica y le coloca incierto entre dos pulsiones constantes: la trágica pereza y la poética melancolía ambas relacionados con Petra (p. 20 y, sobretodo, 29). 
la que este último establece con Ana y causa ulterior aprensión para él por el decaimiento de las propias energías sexuales. Petra se concede, a través de Mesía, el placer de ser buscada por el hombre más deseado de Vetusta y al mismo tiempo sentirse elevada, por medio de esos "amores de señorito" (II, p. 517), al mismo nivel de su ama.

Lo que es notable del personaje de Petra es el modo en que es consciente de sus motivaciones. Los tres hombres que giran alrededor de Anita son exactamente los mismos que ella induce, con adecuados subterfugios, a girar alrededor de sus modos, que incluyen gracias frescas de su cuerpo, pero se sostienen en el atrevimiento de su comportamiento social. Cada uno de ellos está convencido, al menos al principio, de estar en posición dominante respecto a ella: Quintanar porque se proyecta superficialmente en el papel del señor que seduce y compromete la joven en servicio, De Pas porque está convencido, seduciéndola, o dejándose seducir, de que obtendrá el dominio sobre ella para llegar a la Regenta, Mesía porque está convencido de comprar la complicidad de Petra a sus amores en la casa Ozores. Lo que los tres ignoran es que la moza lúbrica tiene razones personales para aceptar, e incluso solicitar, sus atenciones de ellos y que, en realidad, el verdadero control lo ejerce ella. La percepción de haber sido usada por ellos hace estallar la reacción vengativa de Petra que no concede a nadie sentirse superior a su voluntad:

Vengábase protegiendo ahora los amores de Mesía y Ana, 'del idiota de don Víctor' que se ponía a comprometer a las muchachas sin saber de la misa la media; vengábase de la misma Regenta que caía, caía, gracias a ella, en agujero sin fondo, que estaba, sin saberlo la hipocritona, en poder de su criada, al cual el día que le conviniese podía descubrirlo todo... Pero además gozaba de otra venganza más suculenta que todas éstas la endiablada moza. ¿Y el Magistral? El Magistral la había querido engañar, la había hecho suya; ella se había entregado creyendo pasar en seguida a la plaza que más envidiaba en Vetusta, la de Teresina... Pero no fue así; el Magistral non volvió a solicitar a Petra; cuando tuvo que hablarla, 
no fue para asuntos que a ella directamente le importasen, fue... ¡qué vergüenza! Para comprarla como espía! (II, p. 517).

Lo que se pone en acción, sin que los tres hombres se percaten, es una contienda ${ }^{33}$ por el control del cuerpo femenino y su sexualidad, originada por el rechazo por parte de la mujer de dejarse definir dentro de dinámicas masculinas de apropiación y de explotación que lleva consecuencias personales en términos de percepción autobiográfica, pero que sobre todo conlleva recaídas mucho más amplias en el plano de las relaciones intersubjetivas. En el extraordinario capítulo XXVII la especularidad de las dos réplicas estandarizadas y seriales de la femineidad, Ana y Petra, se manifiestan de manera ejemplar. Si la Ozores en ese capítulo, más que en ningún otro, se desahoga y da consistencia a su vena de escritora autobiográfica en la transposición en el cuerpo de la novela, en la primera parte del capítulo, de una autoconciencia crítica y hermosa de su autodescripción ${ }^{34}$, en la segunda parte, en una construcción de espejo, Petra realiza su obra maestra disfrazándose de aldeana, en la salita del monte con un don Fermín que la sigue, a veces cansado, a pesar de la tradicional proeza física, y por fin la toma de posesión del cuerpo del cura en la cabaña en que quizás involuntariamente o quizás con malicia, la doncella deja la liga roja donación de su ama y rival. Es en el cuadro de esta conciencia de sí y en el hecho de que Petra trate de cambiarla en una forma de poder que usar a su ventaja, que se lee la anotación que dice «su hermosura podía excitar deseos, pero difícilmente producir simpatías» (I, pp. 418-9), con el que este personaje aparece desde el principio. Si su conciencia de las dinámicas sexuales y del proprio rol en esas, en relación al género, como a la clase social de pertenencia, resulta una figura de mujer, a modo suyo, fascinante y seductora en contraste con

33 Asumo deliberadamente el modelo de Américo Castro, La Celestina como contienda literaria, Revista de Occidente, Madrid 1965.

34 Una precisión decisiva: «Quintanar ronca, yo escribo» (II, 27, p. 440). 
la represión histérica de la protagonista, la inserción de dichas dinámicas fuera del cuadro de las fantasías sentimentales (dominio femenino), sino en el de la competencia y control del otro (dominio masculino) resulta, al contrario, un personaje inquietante y portador de inestabilidad. Sin embargo, cuando Ana es fuerte - y lo es solo en ese momento de las vacaciones de la solución de continuidad representada por la ruptura del esquema de la rutina de la ciudad de la siesta, en la pax idílica del Vivero, cuando "Vetusta en verano es una Andalucía en primavera" (p. $452)^{35}$ - en ese momento en que es, o por lo menos se considera, ser ella misma autora de las palabras, se enternece con Petra y le parece posible integrarse en una solidaridad entre hermanas:

Petra, la misma Petra, me gusta aquí, en el campo. Se viste como las aldeanas del país, canta con ellas en la quintana, se mete en la danza y toca la trompa con maestría. Ayer, al morir el día, junto a la Puerta Vieja tocaba, con la lengüeta de hierro vibrando entre sus labios, los aires del país monótono y de dulce tristeza. Pepe, el casero, cantaba cantares andaluces convertidos en vetustenses... y Petra tañía la trompa quejumbrosa, y yo sentía lágrimas dulces dentro del pecho... y la vaga esperanza volvía a iluminar mi espíritu. Cuanto más triste la lengüeta de la trompa, más esperanza, más alegría dentro de mí. Todo esto es salud, nada más que salud ${ }^{36}$.

A pesar de la crítica evidente a la hipocresía de la moral burguesa y la denuncia, a través de inquietudes y la enfermedad de la Ozores, de sus falsedades a propósito de la idealización de la mujer, la novela parece proponer como solución posible a tales desviaciones un ajuste más que un abandono definitivo. El adulterio de Ana Ozores se justifica a nivel narrativo por la prolonga-

35 No se puede demostrar, pero tampoco excluir, la reminiscencia de Góngora (Primera Soledad v. 93) donde la alternancia o excursión térmica día / noche salva, según el entusiasta Díez de Rivas, la coherencia del texto censurado por Jáuregui (véase al respecto la ed. De Robert Jammes en Clásicos Castalia, Madrid 1994), p. 216).

36 Ed. Oleza, pp. 449-450. 
da infelicidad matrimonial ${ }^{37}$ y resulta por lo tanto una reacción de la mujer a las presiones de las que fuera víctima. De esto es testimonio la autocrítica de Quintanar respecto a la inoportunidad y crueldad de su matrimonio con una mujer mucho más joven que él y la responsabilidad moral que el marido, y el mismo Frígilis, se atribuyen por haberla desaliñado por tanto tiempo. Además, Ana vive su relación adúltera en una dimensión sobre todo sentimental, considerándola la realización de que habría podido ser la vida matrimonial y sin salir nunca del marco de los tradicionales roles de género que desean a la mujer sensible, pasiva y remisiva. Petra representa en este cuadro a la mujer emancipada que usa el propio cuerpo según sus propios deseos y razones, pero en la novela es tratada como una figura que no suscita simpatía. De todos modos, más allá del comentario del narrador y de las mismas intenciones del autor, es innegable que a este personaje la novela confía algunas de las intuiciones más significativas sobre los acontecimientos, los demás protagonistas, haciendo de ella uno de los lentes a través del cual el lector se puede acercar al análisis del texto y las dinámicas de género que este realiza. Petra, decididamente apolítica, asume así el papel de intérprete directo de una política que solo se trasmite en otro espejo, el deformado y deformador al cual ya Goya había recurrido en Los Caprichos. El sueño de la razón en Vetusta ha producido monstruos, pero ha acabado por desfigurar hasta las ilusiones de la belleza ideal (Ana) o real (Petra).

Giuseppe Grilli

UNIVERSIDAD DE ROMA 3

37 Antonio Vilanova, “El adulterio de Anita Ozores como problema fisiológico y moral", en Clarín y su obra en el Centenario de La Regenta, cit., pp. 43-82. 
